\title{
Language as Investment, Capital, and Economics: Spanish-Speaking English Learners' Language Use and Attitudes
}

\author{
Xiaoping Liang \\ Correspondence: Xiaoping Liang, Department of Linguistics, California State University, 1250 Bellflower \\ Boulevard, Long Beach, California 90840-0902, U.S.A. Tel: 1-562-985-8509. E-mail: xiaoping.liang@csulb.edu
}

Received: September 10, 2012 Accepted: September 24, 2012 Online Published: November 29, 2012

doi:10.5539/ijel.v2n6p1

URL: http://dx.doi.org/10.5539/ijel.v2n6p1

This project was approved by the Institutional Review Board (Protocol \#06-056) of the Office of University Research at California State University, Long Beach

\begin{abstract}
Drawing on the notion of investment in language and identity, the concept of language as capital, and the theory of language as part of economics, this study explores California high-school Spanish-speaking English learners' use of Spanish and English at home, at school, and in the ESL class, and their perceptions on these two languages. Analysis of 37 survey responses reveals that the participants did not have an either-or attitude toward the languages they spoke and concurrently claimed frequent use of and even fluency in the societal language and their heritage language. They did not have a simplistic notion of linguistic identity and simultaneously claimed the English-speaking identity, the Spanish-speaking identity, and the bilingual identity. The results indicate that, rather than a sign of second language insufficiency, bilingual language use in and outside of the ESL class served as an intentional investment in language development and maintenance, identity construction, and preparation for participation in the multilingual marketplace in the internationalized new economy. ESL instructors are encouraged to recognize and acknowledge the role of bilingual language use in class and to create a supportive classroom environment that builds on the linguistic and cultural capital of English learners and fosters the development of both languages into literate, academic and professional capacity.
\end{abstract}

Keywords: language use, language attitudes, Hispanic, Spanish, English learners, identity, linguistic capital, Investment

\section{Introduction}

Recent literature on language use has documented U.S. Spanish-speaking students' different patterns of linguistic practices with parents and with siblings. Hasson (2006) carried out a survey with 202 bilingual Hispanic undergraduate students in south Florida. Among other results, she found that $40.1 \%$ participants reported speaking Spanish with parents while merely 3\% reported speaking Spanish with siblings. On the other hand, $48.2 \%$ of informants stated that they spoke English with siblings whereas only $13.9 \%$ stated that they spoke English with parents. Overall, more participants (62.1\%) used English with parents and siblings at home compared with Spanish ( $43.1 \%$ of participants).

Research on language attitudes of Spanish-English bilingual students demonstrated positive views on bilingual language use in the classroom. Lee (2006) surveyed 280 Latino students enrolled in bilingual classes in seven middle schools (Grades 6-8) in Southern California for their perceptions on bilingual education. 90\% of his participants considered bilingual classes helpful to their educational experience. $74 \%$ responded positively to the use of both Spanish and English in the classroom. 79\% believed that learning in two languages did not interfere with their development of English.

While the research findings on language use and on language attitudes of Spanish-speaking Latinos are impressive, little has been done to explore both together. Additionally, research on English and Spanish use and on language attitudes of Latino students has examined bilingual speakers. Little has been said about English learner (EL) students, "who speak a language other than English at home and who are not proficient in English" (Jepsen \& Alth, 2005, p. v) and are enrolled in English-as-a-second-language (ESL) classes. In California schools, the number of Spanish-speaking English Learners (ELs) has increased rapidly in recent years. 
According to the California Department of Education's (2012) report on the number of ELs by language for 2010-2011, $874544(82.7 \%)$ of the total 1057075 ELs spoke Spanish as their primary language. With these Spanish-speaking EL students, what is happening with their language development and maintenance? What languages do they speak at home, at school, and in the ESL class? How do they perceive the use of different languages in class and in the society at large? Insights into these issues are important to research knowledge because they will open up new avenues for exploration and contribute to a better understanding of Spanish-speaking ELs' language, identity, and educational development. Answers to the above questions are also of vital importance to educational practice because what languages students use in class and how students perceive their use of these different languages directly influence their language development and maintenance. A detailed look into students' language use and language attitudes may directly contribute to instructional effectiveness.

This study aims at exploring the above issues. Specifically, it focuses on how California high school Spanish-speaking EL students use their primary language and English in different contexts of their life and how they perceive their use of two languages in dealing with content and culture learning as well as social interactions in and outside of ESL classes. The purpose of the study is to capture the complexity of how Spanish-speaking teenage ELs' beliefs about language are manifested in their everyday linguistic practices and how their daily language use contribute to their language, identity and educational development.

\section{Theoretical Background}

This study draws on three sets of theoretical approaches to language research: the notion of investment in language and identity (Norton, 1997, 2000; Norton Peirce, 1995), the concept of language as capital (Bourdieu, 1977, 1991; Heller, 2003, 2006), and the theory of language as part of economics (Lamberton, 2002; Marschak, 1965; Vaillancourt, 1982/1983).

\subsection{Investment in Language and Identity}

According to Norton Peirce (1995) and Norton (1997, 2000), learners make an investment when acquiring a second language and expect a good return such as access to resources that are otherwise unavailable for them. Norton Peirce (1995) emphasized that the notion of investment perceived a language learner as having a complex social identity and multiple desires. "An investment in the target language is also an investment in a learner's own social identity, an identity which is constantly changing across time and space" (p. 18).

Employing Norton Peirce's (1995) and Norton's (1997, 2000) notion of investment as an analytical tool, McKay and Wong (1996) looked at four adolescent Chinese immigrant students' language learning experiences in a U.S. school to find out about these students' investment in English and in learner identities. Their data presented "cases of strong Chinese-language retention and strong English acquisition existing side by side, or strong Chinese cultural identification and a strong desire to become American existing side by side" (p. 604).

More recently, Liang (2006) observed 120 Chinese immigrant students in a Canadian high school and interviewed 49 of them to examine classroom language use in relation to individual and group identity and to functional use of Chinese and English. Her interview data demonstrated that the 49 interviewees had multiple and complicated feelings about bilingual language use. These students seemed to have investment in both Chinese and English languages and in membership for both Chinese-speaking peer groups and English-speaking communities.

Most recent research on investment in language and identity in the field of second and foreign language education has explored issues such as the impact of a continued investment in learning and speaking the heritage language on one's identity (Walsh, 2011), the connection between Korean heritage language learners' (re)negotiation of their hyphenated Korean-Canadian identities and their investment in maintaining their heritage language (Shin, 2010), and the pedagogy that recognized students' multiple identities and enhanced student investment in the language practices of the classroom (Norton, 2011).

Regarding Spanish language learning and identity construction, Potowski (2004) studied the quantity and patterns of Spanish use by four students in a Spanish/English dual immersion classroom in Chicago, Illinois. She used the notion of investment to analyze her qualitative data collected through observations and interviews to explain reasons behind students' use of Spanish in class. Her findings showed that the four students spoke Spanish to invest in different and sometimes competing student identities, such as a student who was well-behaved, popular, funny, academically-focused, knowledgeable, or aggressive.

\subsection{Language as Capital}

Proceeding from the economic metaphor of cultural capital (Bourdieu, 1977; Bourdieu, 1991), Heller (2006) 
discussed the notion of language as economic and social capital in her examination on linguistic minorities and modernity. She noted that as globalization was spread through new technology, trade enterprise and international corporations, language became not only a symbol of national or ethnic identity but also a form of economic and social capital. In an earlier work, Heller (2003) explored the relationship of language and identity to the globalized new economy in an ethnographic, sociolinguistic study in two francophone areas of Canada. She argued that language had become a basis for economic mobilization in the globalized new economy.

Pomerantz (2002) examined the way a Spanish-as-a-foreign-language program at a prestigious, internationally oriented U.S. university was organized and how middle- to upper-middle-class monolingual English-speaking students in the program constructed their Spanish user identities. Her observation and interview data collected in an advanced Spanish conversation course demonstrated that students who were going to become doctors, lawyers, and bankers regarded Spanish as a form of economic and social capital for participation in a global, multilingual work order and considered themselves as legitimate users of the Spanish language in this work order. Pomerantz concluded that, in this multilingual marketplace, those who had the resources to successfully cross linguistic and cultural borders would be the powerful.

More recent literature on language as capital has investigated contributions of minority-language children's linguistic, social, and cultural capital to their English literacy development (Peterson \& Heywood, 2007), English learner students' linguistic and cultural capital as major resources to draw on for teaching language and content (Brooks \& Karathanos, 2009), the institutional and professional lack of recognition of the linguistic and cultural capital of multilingual student teachers (Safford \& Kelly, 2010), and how linguistically isolated refugees experienced language as social capital for access to necessary information and social power (Nawyn, Gjokaj, Agbenyiga, \& Grace, 2012).

With regard to Spanish-speakers, Trueba (2002) described the changes of Latino immigrants' multiple ethnic, racial, and cultural identities from marginality to new cultural capital in modern society. This new cultural capital included the abilities to endure hardships and overcome obstacles, to cross ethnic, racial and cultural boundaries, as well as to speak both Spanish and English. Latinos who possessed these abilities would have a large cultural capital and be able to function effectively in a diverse society.

\subsection{The Economics of Language}

In the field of economics, there is a body of literature on the economics of language. Marschak (1965) proposed the concept of language as part of economics because it identified with "the search for optimality in fields extending beyond, though including, the production and distribution of marketable goods" (p. 136). The theoretical discussion on the economics of language related linguistics skills in a second language to different dimensions of economics such as job qualification and employment. As Lamberton (2002) proposed, language skills are "a key ingredient in human capital; a second language is a bankable asset. Language affects job qualifications and ability to find employment" (p. xii).

Vaillancourt's (1982/1983) review of the literature on why individuals learn a second language revealed that the decision was partly based on "the net returns to that investment, that is, the gross returns minus the costs" (p. 164). His evaluation of the literature on the language of work indicated that individuals in industrial societies had little power in determining the language they worked in. "The language of the marketplace is an important determinant of the language of work" (p. 167). The other two determinants included the language of technology used for production and the language skills of the workforce.

The literature on the economics of language has also discussed the relationship between second language skills and individual earnings. In Grenier's (1985) two-language economy model, each person's earnings level was assumed a function of three factors: the person's native language, whether the person is bilingual, and other attributes of the person. Lang (1986) proposed two models of a two-language labor market. In the first model, employers chose whether to hire monolingual or bilingual workers. Bilingual workers' wages would compensate for their cost of becoming bilingual. In his second model, employers hired workers and supervisors. Workers would be paid less while supervisors would be paid more. Bilingual supervisors' wages would compensate for their supervisorial training as well as for the cost of learning the second language. Chiswick and Miller (1995) conducted empirical tests to examine the relationship between immigrants' dominant language proficiency and its effects on their earnings. Their findings showed that, in the United States, Australia, Canada, and Israel, statistically significant higher earnings were connected with fluency in the dominant language (English in the United States and Australia, English or French in Canada, and Hebrew in Israel).

More recent literature on the economics of language confirms the impact of language proficiency on individual earnings (Chiswick \& Miller, 2003; Chiswick \& Wenz, 2006; Goldmann, Sweetman, \& Warman, 2011). For 
example, Azam, Chin and Prakash (2010) found that English-speaking ability raised both men and women's wages in India. Christofides and Swidinsky (2010) reported on substantial rewards to second official language use in Quebec, Canada. The earnings of bilingual Francophones who frequently used English at work were significantly higher compared to those of unilingual Francophones. In the U.S. labor market, the language requirements variables were discovered to have stronger links with earnings for foreign born than for native born in occupations that required greater English skills (Chiswick \& Miller, 2010). Other variables being the same, earnings among immigrants in the United States, Canada, Australia, Israel and Bolivia were greater for those more proficient in the destination language (Chiswick, 2009).

The notion of investment in language and identity, the concept of language as capital, and the theory of language as part of economics provide important tools to investigate the complex relationship between high school Spanish-speaking EL students' everyday language use and their ideologies of language as linguistic capital in their investment in identity construction and social and economic advancement. The two specific research questions this study asks are as follows: 1) How do Californian high-school Spanish-speaking EL students report their use of Spanish and English at home, at school, and in the ESL class? 2) How do these students perceive the use of these two languages in and outside of the ESL class?

\section{Research Methods}

This study was part of a larger research project on Spanish-speaking EL students' language, identity, and educational development. The project was largely qualitative. This study employed some quantification for data analysis to compare quantitative results with qualitative data (Creswell, 2009). It examined issues of language use and language attitudes from EL students' perspectives.

\subsection{Research Site}

The study was conducted in Harbor High School (a pseudonym) located in Southern California, the United States. Harbor was chosen as a research site because it had a high population of Spanish-speaking students. The 5 -year history (2006-2011) of the school's student racial ethnicity showed that an average of $89 \%$ of the student body was Hispanic. The school's Academic Performance Index (API) change demonstrated a continual improvement of student academic performance between 2008 and 2011. Nevertheless, the results of California High School Exit Examination (CAHSEE) in 2011 indicated that 53\% of students in the school were not proficient in Mathematics and 55\% were not proficient in English-Language Arts. For the three-year period between $2007-2010$, the four-year graduation rates were $75.2 \%, 79.4 \%$ and $76.4 \%$ respectively. Of the 2516 students included in 2011 API report, 2027 (80.5\%) were categorized as 'Socioeconomically Disadvantaged.' Over the five years between 2006 and 2011, an average of $21 \%$ of all students in the school was enrolled as English learners in ESL classes. On average, $98 \%$ of these students spoke Spanish as their first language. Each year, the percentage of ELs reclassified as 'Fluent English Proficient' was 7.38, 8.71, 7.06, 11.50 and 12.11, the average being $9.35 \% .90 .65 \%$ of EL students in this school stayed in ESL classes for more than one year.

\subsection{Participants}

Altogether, 40 EL students participated in a survey. Data from three students were excluded from this study because they spoke another language at home and did not speak Spanish. The 37 participants in this study were Spanish-speaking ELs in two ESL classes with 24 in one class and 13 in the other. They were between the age of 13 and 19, the average being 16 . Twenty of them (54\%) were female while $17(46 \%)$ were male. Twenty-seven (73\%) were born in another country and moved to the United States later in life. Ten (27\%) students' father's highest level of education was elementary; fifteen's $(40.5 \%)$ was secondary; three's $(8.1 \%)$ was college; and another three's $(8.1 \%)$ was university. Twelve $(32.4 \%)$ students' mother's highest level of education was elementary; Ten's (27\%) was secondary; Eight's (21.6\%) was college; and two's (5.4\%) was university. Thirty (81\%) of the 37 participants were eligible for free lunches at school based on their low family income.

All 37 participants' parents usually spoke Spanish to each other at home. One (2.7\%) student's parents also spoke English to each other. Thirty-four (91.9\%) participants' father usually communicated with them in Spanish while the remaining three (8.1\%) participants' father usually communicated with them in English. Thirty-six (97.3\%) participants' mother usually spoke to them in Spanish. One (2.7\%) participant's mother usually spoke to her in English. Twenty-one (56.8\%) participants spoke Spanish with their siblings whereas twenty-four (64.9\%) spoke English with their siblings. Eight students (21.6\%) spoke both Spanish and English with their siblings. Thirty participants (81.1\%) reported that they spoke Spanish most fluently. Eleven (29.7\%) claimed that they spoke English most fluently. Four (10.8\%) asserted that they spoke Spanish and English equally fluently. 


\subsection{Data Collection and Analysis}

A written survey was carried out to investigate the Spanish-speaking EL students' language use and language attitudes. The survey questionnaire had seven parts with 82 questions. It was piloted beforehand with high school students in another location. Due to the limit on length, this study focused on responses to questions on language use at home, at school and in the ESL class, and on attitudes toward language use in the ESL class and in the society at large (see Appendix). The questionnaire was first developed in English by the researcher and then translated into Spanish by a Spanish-speaking graduate assistant. Both versions of the questionnaire were double checked by the two bilingual ESL teachers of the 37 participants and the researcher's Institutional Review Board. Based on the ESL teachers' recommendation, the English version was used when the survey was conducted in the two ESL classes during school time. The ESL teachers distributed and collected the survey questionnaires. Participants were instructed to respond in a language they felt most comfortable with, whether it was English or Spanish. The researcher was present during the survey to clarify participants' questions.

The questions were quantitative and qualitative. Quantitative questions provided three, four, or five prompts. Participants were instructed to choose either one or more from the listed prompts. Qualitative questions elicited students' reasons and beliefs behind their responses to the quantitative questions. The quantitative survey responses were calculated for frequency distribution to find out the number of times each response occurred and for percentage to uncover the quantity of different responses in relation to one another. The qualitative survey responses were analyzed using the inductive analysis strategy (McMillan \& Schumacher, 2001). The written responses were first sorted out by individual informants and then grouped together. Circumstances and reasons for using Spanish and English in various contexts and explanations for language preferences were categorized by constant comparison to determine their representativeness. The names of the categories such as "when talking to friends", "learn English faster" and "getting a good job" came from the responses and were words used by participants.

\section{Findings}

This study examines California high-school Spanish-speaking EL students' reported use of Spanish and English at home and at school and their attitudes toward the development and maintenance of these two languages in and outside of the ESL class. The findings demonstrate that the students under study not only spoke Spanish and English in different settings of their life but also intentionally chose to use both languages simultaneously in these contexts.

\subsection{Simultaneous Use of Two Languages}

In answer to research question one that explores language use, a close analysis of survey responses indicates that the EL students in this study spoke English and Spanish concurrently at home, at school, and in the ESL class (see Table 1).

Table 1. Languages spoken at home, at school, and in the ESL class

\begin{tabular}{llll}
\hline Question No. & Languages spoken & No. of respondents & $\%$ \\
\hline 7 & Spanish at home & 37 & 100 \\
8 & English at home & 30 & 81.1 \\
16 & Spanish at school & 35 & 94.6 \\
17 & English at school & 35 & 94.6 \\
28 & English in the ESL class & 34 & 91.9 \\
29 & Spanish in the ESL class & 32 & 86.5 \\
\hline
\end{tabular}

Survey responses on language use revealed a significant overlap between English and Spanish spoken at home, at school, and in the ESL class. All 37 EL students testified that they spoke Spanish at home (Question 7) while 30 stated that they also spoke English at home (Question 8). A prevailing number of participants reported speaking both languages at school as well. The overlap between Spanish (Question 16) and English (Question 17) use in the school context was bigger than that at home. A dominant number of respondents were also found to 
speak two languages concurrently in ESL classes at school. When asked how often they spoke English (Question 28) and Spanish (Question 29) in the ESL class, there was a major overlap between the two languages used.

In answer to a follow up inquiry to Question 28 "Under what circumstances do you tend to speak English in the ESL class?" 15 (40.5\%) participants reported that they spoke English when asking and answering questions. Ten (27\%) wrote that they spoke English when working in groups and when some group members did not understand Spanish. Five (13.5\%) stated that they spoke English when giving presentations and when making comments or giving opinions in class discussion.

For the follow up query to Question 29 "Under what circumstances do you tend to speak Spanish in the ESL class?" 13 informants (35.1\%) answered that they spoke Spanish when talking to friends particularly when their friends did not understand English. As one student wrote, "When the other people talk to me in Spanish I talk back Spanish too" (ESL2A.10). Ten respondents (27\%) replied that they spoke Spanish when they did not know how to pronounce the English words they wanted to say or when they did not know how to express themselves in English. Three students (8\%) claimed that they spoke Spanish when they did not understand the teacher's instruction on content or on a task.

When asked "Which language do you speak most often when you work in pairs or small groups in your ESL class?" (Question 33), there was a noteworthy overlap between Spanish and English use. 26 students (70.3\%) selected Spanish and 16 (43.2\%) chose English. Five (13.5\%) participants selected both Spanish and English. Being able to practice more and learn more English and having to speak the language because it was an English class were two major explanations for speaking English during group work. As for the justifications for speaking Spanish, seven students (18.9\%) testified that everyone else in the group spoke Spanish so they spoke Spanish too. Another seven (18.9\%) considered it easier to communicate in Spanish because they could explain better and understood each other more. Four students $(10.8 \%)$ added that they sometimes did not know some of the words in English. Three students (8.1\%) explained that some of their group members did not speak English well. Another three $(8.1 \%)$ reported that they were shy and were afraid that others would make fun of them for speaking English.

\subsection{Side-by-Side Needs for Two Languages}

In answer to research question two that explores language attitudes, a careful examination of the survey responses indicates that the Spanish-speaking EL students in this study had side-by-side needs for English as well as Spanish in the ESL class and in the bigger society.

\subsubsection{Side-by-Side Needs for Two Languages in the ESL Class}

A predominant number of students had a positive attitude toward the ESL class. They expressed a need to speak English in the ESL class. At the same time, they also articulated a need to speak Spanish in class.

\subsubsection{A Positive Attitude toward the ESL Class}

The majority of respondents liked English as a subject and considered the ESL class useful and necessary (see Table 2).

Table 2. Positive attitudes toward the ESL class

\begin{tabular}{llll}
\hline Question No. & Responses & No. of respondents & $\%$ \\
\hline 53 & Liked English as a subject. & 33 & 89.2 \\
54 & Considered the ESL class useful in general. & 29 & 78.4 \\
55 & Considered taking the ESL class necessary. & 33 & 89.2 \\
\hline
\end{tabular}

When further asked to clarify the reasons they liked the ESL class, respondents gave the following explanations. They had the opportunity to learn, to know and to speak English as a new language (11 students, 29.7\%). As a result, they could be bilingual speaking two languages (three students, $8.1 \%$ ) and talk to and communicate with more people (six students, 16.2\%). Additionally, English and the content taught in class were fun, interesting, important and necessary, and they felt happy in class (seven students, $18.9 \%$ ).

Many respondents considered the ESL class useful (Question 54) because it helped them learn and speak English (seven students, 18.9\%) and understand school subject (four students, 10.8\%) so they could get into college (one student, $2.7 \%$ ) or get a better job (one student, 2.7\%). More students considered the ESL class necessary (Question 
55) because many of them did not speak English (five students, 13.5\%). They needed to learn, understand and speak English (8 students, $21.6 \%$ ) to understand teachers' instruction so that they could learn school subjects, graduate from high school and get a diploma (five students, 13.5\%). If they did not speak English, they might not get a good job (two students, 5.4\%).

\subsubsection{A Need to Speak English in the ESL Class}

In their survey responses, the majority of participants conveyed a need to speak English in the ESL class. Thirty (81\%) respondents considered it necessary that students should speak only English in the ESL class (Question 56). They believed they could learn and practice more English that way (10 students, 27\%) and learn English faster (7 students, $18.9 \%)$. Below are a few quotations from participants' written responses. In these and subsequent quotations, participants' spelling, punctuation and grammatical errors were not corrected to accurately reflect their language proficiency. Italics stand for responses made in Spanish. Words in brackets were added by the researcher to avoid ambiguity. At the end of each quotation, the participant's code was provided to give individual voice to each student.

- $\quad$ Because we need to practice more English (ESL2A.20)

- $\quad$ because the most you speak that more you learned. (ESL3.06)

- like that you could learn more English and your going to get to speak it very well (ESL3.13)

- $\quad$ because is an English class. You should speak english. (ESL3.11)

- because If you speak Englis in the class you will lern more faster (ESL3.04)

\subsubsection{A Need to Speak Spanish in the ESL Class}

Some EL students expressed a desire to speak Spanish in class as well. Fifteen respondents (40.5\%) considered it necessary that students should also be allowed to speak Spanish in the ESL class (Question 57). Their major reason was that some classmates did not speak much English. As they wrote in their survey responses:

- Because they don't speak in English, they can help themself in spanish. (ESL2A.11)

- they could speak spanish just in case that they don't understand. (ESL3.03)

- because mabe they don't now [know] something and they whan [want] to ask the person on the side of them (ESL3.04)

- Because they might neat [need] to say something but they don't know how to say it in English. (ESL3.09)

4.2.2 Side-by-Side Needs for Two Languages in the Society at Large

In their written responses, many participants under study articulated a necessity for both English and Spanish in the state of California. They considered English and Spanish equally important and needed in California. They also contended that residents in the state should be encouraged to speak or to learn to speak both languages.

\subsubsection{A Need for English in California}

A large number of participants had a positive attitude toward English. Thirty (81.1\%) of the 37 consented that in California being able to speak English was more important than being able to speak Spanish (Question 60). In the words of these participants:

- Because all here speak english so we need to learn. (ESL2A, 10)

- Because we are in USA. (ESL2A, 17)

- Because this is an english-speaker country and we have to learn this lenguage. (ESL3, 03)

Thirty-one informants (84\%) considered it important that people in California should be able to speak English (Question 64) because it is the societal language in the state and in the country (seven students, 18.9\%). In addition, being able to speak English would provide them more opportunities for a successful future such as getting a better job with higher pay (nine students, $24.3 \%$ ). As they put it:

- Because they want to find I [a] job to work. You have to speak English. (ESL3.06)

- I think so because they have most opportunities. (ESL3.07)

- It's very important because if you don't know english, you don't have a good job. (ESL3.08)

- so they could get a better job (ESL3.13)

For similar explanations, $30(81 \%)$ participants concurred with the statement that people in California who do not speak English should be encouraged to learn it (Question 65). Also mentioned in their written responses was the reason for a better communication with people who did not speak Spanish:

- because the [they] can communicate with other people that don't speak Spanish. (ESL2A.08)

- because the people need to speak English for a better comunication. (ESL2A.18) 
In the same way, $24(64.9 \%)$ participants disagreed with the statement that it was sufficient for people in California to speak only Spanish (Question 66). They argued that, without English, they would not be able to communicate with people who did not speak Spanish and they would have fewer opportunities for a good job. As they wrote:

- because this people can do not have mos [most] opportunities. (ESL3.07)

- $\quad$ no ... because you don't communicate well at your job, you have a barrier with that. (ESL3.08)

\subsubsection{A Need for Spanish in California}

The majority of the participants in this study also conveyed a desire for the Spanish language in the state of California. Twenty-seven students (73\%) agreed that in California being able to speak Spanish was as important as being able to speak English (Question 61). They considered both languages equally important and wanted to be bilingual. As they responded in the survey:

- Because I think both languages are very important. (ESL2A.08)

- $\quad$ speaking both lenguages we could help persons who doesn't speak either english or spanish. (ESL3.03)

- If you now [know] this two languages you will get better paid in your work if you talk this two languages (ESL3.04)

Likewise, 27 (73\%) respondents considered it important that people in California should be able to speak Spanish (Question 62) due to the fact that many residents in the state spoke Spanish as their primary language and some of them did not speak English. Being able to speak Spanish in addition to their first language would enable Californians to be bilingual, which would enhance their opportunities of communicating with Spanish-speaking residents. Following are some extracts from student survey responses:

- Because the mayority of imigrants speak spanish and you need to understand them (ESL3.14)

- Because some people doesn't know how to speak english like parents and young adults. (ESL3.12)

- Because they might not no [know] English. (ESL3.09)

- Because we can be bilinguals people. (ESL2A.08)

For similar incentives, 23 participants (62\%) responded positively to the statement that people in California who do not speak Spanish should be encouraged to learn it (Question 63). They explained:

- Because is more better speak two lenguages (ESL2A.18)

- Becaus there is 10 million latin-american people in california you need or are going to comunicate with one of them. (ESL3.01)

- Because Spainsh is a beautiful language. (ESL2A.08)

- because you can learn a new culture. (ESL3.08)

Most participants responded negatively to the statement that in California being able to speak Spanish was more important than being able to speak English (Question 59). Nevertheless, 15 (40.5\%) did agreed with the statement because of the location of the state (on the border with Spanish-speaking Mexico) and the number of Spanish-speaking residents in the state. In the words of these students:

- because California is where more [Spanish-speaking people reside]. (ESL2A.06)

- there are many people that speak spanish. (ESL2A.09)

To summarize the findings with regard to the two research questions, the 37 California high school Spanish-speaking EL students in this study reported speaking both English and Spanish at home, at school, and in the ESL class. There were significant overlaps between the two languages reportedly used in the above mentioned situations. These students also expressed side-by-side needs for English as well as Spanish in and outside of the ESL class. They asserted the importance of both languages to their education and their future life. They wanted to learn English quickly and speak the language well. At the same time, they also appeared determined to maintain Spanish, their heritage language. They wanted to be fluent bilinguals so they could communicate with both Spanish and English speakers, get a good job and live a better life.

\section{Discussion}

The findings on language use and language attitudes present a complex picture of the intertwining of language, identity and education for Spanish-speaking high school EL students. The complexity was expressed through three sets of interrelations: two languages and multiple identities, bilingual language use and linguistic capital, and the economics of learning English and becoming bilingual. 


\subsection{Investment in Two Languages and Multiple Identities}

The participants' side-by-side needs for English and Spanish in the ESL class and in the society at large may indicate that these students did not have any simplistic notions of linguistic identity. It is possible that they had multiple desires (Kramsch, 2000) for languages and identities. They might simultaneously invest in both English and Spanish and, in return, expect to establish multiple identities.

\subsubsection{Investment in an English-Speaking Identity}

In varying settings of their daily life, the participants under study seemed to be engaged in a constant search for an English-speaking identity. At school, most of them had a positive attitude toward the ESL class and considered it useful. Many participants deemed it necessary that EL students should speak only English in the ESL class. They wanted to learn more English and learn it fast so they could fully participate in subject matter learning in English and be successful in high school education. At home, as high as $81.1 \%$ of the participants reported speaking English with siblings and sometimes parents. In the society at large, most students considered it important that residents in California should be able to speak English and those who did not be encouraged to learn it.

These students' desire for an English-speaking identity in the ESL class, at home and in the bigger society appeared to be linked to their beliefs about language in relation to nationhood. They seemed to have equated "speaking English" with "being American." "We are in USA" (ESL2A.17). "English is the language here" (ESL2A.12). "This is an english-speaker country and we have to learn this lenguage" (ESL3.03). These written survey responses served as a testimony of participants' ideology of English speaking and American identity.

\subsubsection{Investment in a Spanish-Speaking Identity}

In their everyday life, the 37 participants also seemed to be involved in a continuous confirmation and reconfirmation of a Spanish-speaking identity. At school, the English language occupied all instruction time and dominated the overall school environment. Nevertheless, $86.5 \%$ of participants reported speaking Spanish in the ESL class. All participants reported speaking their heritage language at home. $73 \%$ of participants concurred that, in California, being able to speak Spanish was as important as being able to speak English and that residents who did not speak Spanish should be encouraged to learn it.

Heritage language use is regarded as an internal psychological dimension of ethnicity. The high frequency of reported Spanish language use at home marked heritage language use as an activity that connected these students to their families. It also seemed to function as an important symbol of belonging, of membership in Spanish-speaking communities of practice for the students. "There is 10 million latin-american people in california you need or are going to comunicate with one of them" (ESL3.01). "Spanish is a beautiful language" (ESL2A.08). "You can learn a new culture" (ESL3.08). These written responses revealed students' pride in speaking Spanish and their desire to maintain the Spanish-speaking identity. A few students who felt strongly about speaking Spanish in California made a case for second language learners' linguistic rights (Baltodano, 2005) and declared "We have a right to speak our language" (ESL2A.09) "because it [California] was part of Mexico" (ESL2A.06).

\subsubsection{Investment in a Bilingual Identity}

The survey results also seem to imply that students in this study did not consider language identities as an either-or choice. They appeared to have a desire to live their lives in two languages (Watkins-Goffman, 2001), a desire to move between two languages without suffering loss of either English- or Spanish-speaking identity, a desire for a hybrid bilingual identity. The overlaps between reported English and Spanish use at home, at school, and in the ESL class were remarkable. In their written responses to different survey questions, many participants stated that both English and Spanish were important in California and that they needed both. Some explicitly articulated their goal to be bilingual. "I want to be bilingual" (ESL2A.15). "We can be bilinguals people" (ESL2A.08). They considered being bilingual an advantage "Because is more better speak two lenguages" (ESL2A.18). "is better when you speak two languages" (ESL3.11). They also had sound reasons for their ambition. "Because I could speak two languages an [and] communicate with more and new people" (ESL3.03). "Speaking both lenguages we could help persons who doesn't speak either english or Spanish" (ESL3.03). For these students, a bilingual identity was both natural and beneficial.

\subsection{Bilingual Language Use as Linguistic Capital}

The significant overlaps between reported simultaneous use of Spanish and English at home, at school and in the ESL class suggest that EL students in a bilingual community such as California may not have a simplistic either-or attitude toward the languages they speak. They may simultaneously claim frequent use of both 
languages, in this case, the heritage language Spanish and the societal language English. Contrary to a common view that considered first language use as an indicator of second language inadequacy and a retreat for communicative purposes (Echevarria \& Graves, 1998), bilingual language use appeared to be a deliberate choice by the EL students in this study.

The 37 participants all gave reasons for speaking Spanish in the ESL class and during group work. In most cases, Spanish was used for learning purposes such as to clarify understanding of teacher's instructions, of group tasks, and of English words; to help other students who had difficulty with English; to manage the challenge of completing group work in a limited class time; and to express their ideas more clearly. Used this way, Spanish appeared to function more than just a convenient retreat or cover for students' failure in the mastery of the English language. It, together with English, served as funds of knowledge (Mercado, 2005) for students' language and educational development. For these students, bilingual language use was an important addition to their repertoire of linguistic capital in classroom communication.

\subsection{The Economics of Learning English and Becoming Bilingual}

The Spanish-speaking EL students in this study seemed pragmatically oriented in their ideologies about language development and maintenance. This pragmatic stance may be shaped by the socioeconomic and political realities in which the participants lived. Although 29 respondents (78.4\%) considered the ESL class useful (Question 54) because it helped them learn and speak English and understand school subjects, only one student explicated her intention of going to college. "Because if I don't now [know] English I will not pass to college" (ESL3.04). On the other hand, five students (13.5\%) responded to Question 55 that high school EL students should take the ESL class so they could graduate and get a diploma. In their responses to Question 64, nine students (24.3\%) associated being able to speak English with more opportunities for employment. They hoped to find a better job with higher earnings that would compensate for the cost (in time and effort, for example) of learning English as a second language. Among participants' written responses to questions on language attitudes, there were 27 replies given by 17 different participants (45.9\%) that related language abilities, particularly the ability of Spanish-speaking immigrants to speak fluent English, to economic prospects. For these students, learning English was more than an investment in language and identities. It was also the means to accumulate the linguistic capital necessary for participation in an English-speaking marketplace.

Five of these 17 participants emphasized the importance of becoming bilingual to professional and economic opportunities. One disagreed with the statement that in California being able to speak English is more important than being able to speak Spanish (Question 60) and said "no ... because with the two languages you can get a better job" (ESL3.08). Another wrote "being belingue [bilingual] in the future people who know English and other language has more oportunities to get a better job \& life" (ESL3.10). One strongly agreed with the statement that in California being able to speak Spanish was as important as being able to speak English (Question 61) and explained "If you now [know] this two languages you will get better paid in your work if you talk this two languages" (ESL3.04). Another considered it very important that people in California should be able to speak Spanish (Question 62) "Because the people that speak English and Spanish has a better work" (ESL2A.18). Yet another agreed with the statement that people in California who did not speak Spanish should be encouraged to learn it (Question 63) "Because they can get more money" (ESL2A.22). Being bilingual was seen by these students as a "bankable asset" (Lamberton, 2002) for the social mobility and economic advancement of not only Spanish-speaking Latinos but also English speakers and other non-Spanish speakers in a globalized new economy at a general level and in a multilingual marketplace such as Southern California more specifically.

\section{Conclusion}

To summarize the above discussion, high school Spanish-speaking English learners in a multilingual society such as Southern California may not have an either-or attitude toward the languages they speak and may concurrently claim frequency of use and even fluency in the societal language as well as their native tongue. They may not have a simplistic notion of language identity and may simultaneously claim multiple language identities such as the English-speaking identity, the Spanish-speaking identity, and the bilingual identity. Rather than a sign of second language insufficiency, bilingual language use may be an intentional investment EL students make in language development and maintenance, identity construction, and preparation for participation in the multilingual marketplace in the internationalized new economy. The findings of this study have important implications for researchers and practitioners working with Spanish-speaking EL students in various educational environments.

\subsection{Implications for Further Research}

Much research literature on Spanish-speaking Latino immigrants looks at either their language use or their 
language attitudes. Little has been said about both together. The present study shows that there may be important relationships between Spanish-speaking EL students' beliefs about language and their reported everyday linguistic behaviors that deserve investigation. For further exploration, researchers may need to take account of EL students' language attitudes in relation to their actual discursive practices in the ESL class and during group work. Hopefully, such an approach will contribute to a better understanding of the communicative functions of bilingual language use in classroom interactions (Liang \& Mohan, 2003) and of the complex relations between language, identity and schooling for English learners.

\subsection{Implications for Teachers}

Several implications can be drawn from the findings of the current study for classroom practitioners. First, contrary to the fallacy that immigrants and their children do not learn English and that they cling to their home language (Tse, 2001), Spanish-speaking EL students may have a very positive attitude toward learning English and gaining an English-speaking identity but not at the expense of learning to forget (Baez, 2002) their heritage language and the Spanish-speaking identity. Their unequivocal desire to learn English may be accompanied by a strong attachment to Spanish for identity, cultural and economic reasons.

Second, whether encouraged or discouraged, bilingual language use may be a social-emotional need (Blanco-Vega, Castro-Olivo, \& Merrell, 2008) and a strategic investment of EL students and, hence, a conscious learner-chosen linguistic practice in classroom communication. It may serve important functions in EL students' content and culture learning as well as social interactions in ESL classes. ESL teachers may need to recognize and acknowledge the role of bilingual language use in English learners' language development and maintenance, identity construction, and educational experience.

Third, demanding that EL students speak only English in class may help create salient cultural conflicts regarding language (Blanco-Vega, et al., 2008) and the experience of being tongue-tied (Santa Ana, 2004), which may, directly or indirectly, contribute to institutional co-construction of Latino students' eventual drop out (Brown \& Rodriguez, 2009). Instead, ESL teachers can create a supportive classroom environment that builds on the strength (Zentella, 2005) in EL students' heritage language and literacy. When heritage language and literacy are treated as linguistic and cultural capital and assets in class, English learners may feel safe and encouraged to develop both languages into literate, academic, and professional capacities.

\section{Acknowledgements}

The author is deeply indebted to the two high school ESL teachers and their EL students for their permission to conduct the research in their classes. Debts are also owed to John Attinasi and Sara Smith, whose valuable comments and suggestions contribute to the article in important ways.

\section{References}

Azam, M., Chin, A., \& Prakash, N. (2010). The returns to English-language skills in India. IZA Discussion Papers, No. 4802. Bonn, Germany: Institute for the Study of Labor (IZA).

Baez, B. (2002). Learning to forget: Reflections on identity and language. Journal of Latinos and Education, 1(2), 123-132. http://dx.doi.org/10.1207/S1532771XJLE0102_4

Baltodano, M. P. (2005). What happened to the linguistic rights of second language learners in California. In J. Cohen, K. T. McAlister, K. Rolstad, \& J. MacSwan (Eds.), Proceedings of the $4^{\text {th }}$ International Symposium on Bilingualism (pp. 175-185). Somerville, MA: Cascadilla Press.

Blanco-Vega, C. O., Castro-Olivo, S. M., \& Merrell, K. W. (2008). Social-emotional needs of Latino immigrant adolescents: A sociocultural model for development and implementation of culturally specific interventions. Journal of Latinos and Education, 7(1), 43-61. http://dx.doi.org/10.1080/15348430701693390

Bourdieu, P. (1977). The economics of linguistic exchanges. Social Science Information, 16, 645-668. http://dx.doi.org/10.1177/053901847701600601

Bourdieu, P. (1991). Language and symbolic power. Cambridge, MA: Harvard University Press.

Brooks, K., \& Karathanos, K. (2009). Building on the cultural and linguistic capital of English learner (EL) students. Multicultural Education, 16(4), 47-51.

Brown, T. M., \& Rodriguez, L. F. (2009). School and the co-construction of dropout. International Journal of Qualitative Studies in Education, 22(2), 221-242. http://dx.doi.org/10.1080/09518390802005570

California Department of Education, Educational Demographics Office. (2012). Statewide English learners by language and grade 2010-11. Retrieved August 22, 2012, from 
http://data1.cde.ca.gov/Dataquest/LEPbyLang1.asp?cYear=2010-11\&cChoice=LepbyLang1\&cTopic=LC\& cLevel=State

Chiswick, B. R. (2009). The economics of language: An introduction and overview. In T. Wiley, J. S. Lee, \& R. Rumberger (Eds.), The education of language minority immigrants in the United States (pp. 72-91). Tonawanda, N.Y.: Multilingual Matters.

Chiswick, B. R., \& Miller, P. W. (1995). The endogeneity between language and earnings: International analyses. Journal of Labor Economics, 13(2), 246-288. http://dx.doi.org/10.1086/298374

Chiswick, B. R., \& Miller, P. W. (2003). The complementarity of language and other human capital: Immigrant earnings in Canada. Economics of Education Review, 22(5), 469-480. http://dx.doi.org/10.1016/S0272-7757(03)00037-2

Chiswick, B. R., \& Miller, P. W. (2010). Occupational language requirements and the value of English in the U.S. labor market. Journal of Population Economics, 23(1), 353-372. http://dx.doi.org/10.1007/s00148-008-0230-7

Chiswick, B. R., \& Wenz, M. (2006). The linguistic and economic adjustment of Soviet Jewish immigrants in the United States, 1980 to 2000. Research in Labor Economics, 24, 179-216. http://dx.doi.org/10.1016/S0147-9121(05)24006-2

Christofides, L. N., \& Swidinsky, R. (2010). The economic returns to the knowledge and use of a second official language: English in Quebec and French in the rest-of-Canada. Canadian Public Policy, 36(2), 137-158. http://dx.doi.org/10.3138/cpp.36.2.137

Creswell, J. W. (2009). Research design: Qualitative, quantitative, and mixed methods approaches (3rd ed.). Thousand Oaks, CA: SAGE Publications, Inc.

Echevarria, J., \& Graves, M. (1998). Sheltered content instruction: Teaching English language learners with diverse abilities. Needham Heights, MA: Allyn \& Bacon.

Goldmann, G., Sweetman, A., \& Warman, C (2011). The portability of new immigrants' human capital: Language, education and occupational matching. IZA Discussion Papers, No. 5851. Bonn, Germany: Institute for the Study of Labor (IZA).

Grenier, G. (1985). Bilinguisme, transferts linguistiques et revenus de travail au Québec: Quelques éléments d'interaction. In F. Vailancourt (Ed.), Éxonomie et Langue (pp. 243-287). Québec: Éditeur Officiel.

Hasson, D. J. (2006). Bilingual language use in Hispanic young adults: Did elementary bilingual programs help? Bilingual Research Journal, 30(1), 45-64. http://dx.doi.org/10.1080/15235882.2006.10162865

Heller, M. (2003). Globalization, the new economy, and the commodification of language and identity. Journal of Sociolinguistics, 7(4), 473-492. http://dx.doi.org/10.1111/j.1467-9841.2003.00238.x

Heller, M. (2006). Linguistic minorities and modernity: A sociolinguistic ethnography (2nd ed.). New York, NY: Continuum.

Jepsen, C., \& de Alth, S. (2005). English learners in California schools. San Francisco, CA: Public Policy Institute of California.

Kramsch, C. (2000). Social discursive constructions of self in L2 learning. In J. Lantolf (Ed.), Sociocultural theory and second language learning (pp. 133-153). Oxford: Oxford University Press.

Lamberton, D. M. (Ed.) (2002). The economics of language. Northampton, MA: Edward Elgar Publishing, Inc.

Lang, K. (1986). A language theory of discrimination. The Quarterly Journal of Economics, 100, 363-381. http://dx.doi.org/10.2307/1891120

Lee, S. K. (2006). The Latino students' attitudes, perceptions, and views on bilingual education. Bilingual Research Journal, 30(1), 107-122. http://dx.doi.org/10.1080/15235882.2006.10162868

Liang, X. (2006). Identity and language functions: High-school Chinese immigrant students' code-switching dilemmas in ESL classes. Journal of Language, Identity, and Education, 5(2), 143-167. http://dx.doi.org/10.1207/s15327701jlie0502_3

Liang, X., \& Mohan, B. A. (2003). Dilemmas of cooperative learning and academic proficiency in two languages. Journal of English for Academic Purposes, 2(1), 35-51. http://dx.doi.org/10.1016/S1475-1585(02)00032-2 
Marschak, J. (1965). Economics of language. Behavioral Science, 10(2), 135-140. http://dx.doi.org/10.1002/bs.3830100203

McKay, S. L., \& Wong, S. C. (1996). Multiple discourses, multiple identities: Investment and agency in second-language learning among Chinese adolescent immigrant students. Harvard Educational Review, 66, 577-608.

McMillan, J. H., \& Schumacher, S. (2001). Research in education: A conceptual introduction (5th ed.). New York, N.Y.: Longman.

Mercado, C. I. (2005). Seeing what's there: Language and literacy funds of knowledge in New York Puerto Rican homes. In A. C. Zentella (Ed.), Building on strength: Language and literacy in Latino families and communities (pp. 134-147). New York, NY: Teachers College Press.

Nawyn, S. J., Gjokaj, L., Agbenyiga, D. L., \& Grace, B. (2012). Linguistic isolation, social capital, and immigrant belonging. Journal of Contemporary Ethnography, 41(3), 255-282. http://dx.doi.org/10.1177/0891241611433623

Norton, B. (1997). Language, identity, and the ownership of English. TESOL Quarterly, 31, 409-429. http://dx.doi.org/10.2307/3587831

Norton, B. (2000). Identity and language learning: Gender, ethnicity, and educational change. New York, N.Y.: Longman.

Norton, B. (2011). The practice of theory in the language classroom. Issues in Applied Linguistics, 18(2), 171-180.

Norton Peirce, B. (1995). Social identity, investment, and language learning. TESOL Quarterly, 29, 9-31. http://dx.doi.org/10.2307/3587803

Peterson, S. S., \& Heywood, D. (2007). Contributions of families' linguistic, social, and cultural capital to minority-language children's literacy: Parents', teachers', and principals' perspectives. The Canadian Modern Language Review/La Revue canadienne des langues vivantes, 63(4), 517-538. http://dx.doi.org/10.3138/cmlr.63.4.517

Pomerantz, A. (2002). Language ideologies and the production of identities: Spanish as a resource for participation in a multilingual marketplace. Multilingua, 21(2-3), 275-302.

Potowski, K. (2004). Student Spanish use and investment in a dual immersion classroom: Implications for second language acquisition and heritage language maintenance. The Modern Language Journal, 88(1), 75-101. http://dx.doi.org/10.1111/j.0026-7902.2004.00219.x

Safford, K., \& Kelly, A. (2010). Linguistic capital of trainee teachers: Knowledge worth having?. Language and Education, 24(5), 401-414. http://dx.doi.org/10.1080/09500781003695567

Santa Ana, O. (Ed.) (2004). Tongue-tied: The lives of multilingual children in public education. Lanham, MD: Rowman \& Littlefield Publishers.

Shin, J. (2010). Critical ethnography of a multilingual and multicultural Korean language classroom: Discourses on identity, investment and Korean-ness. Dissertation Abstracts International, A: The Humanities and Social Sciences, 71(6), 1981.

Trueba, H. T. (2002). Multiple ethnic, racial, and cultural identities in action: From marginality to a new cultural capital in modern society. Journal of Latinos and Education, 1(1), 7-28. http://dx.doi.org/10.1207/S1532771XJLE0101_2

Tse, L. (2001). “Why don't they learn English?”: Separating fact from fallacy in the US language debate. New York: Teachers College Press.

Vaillancourt, F. (1982/1983). The economics of language and language planning. Language Problems and Language Planning, 7(2), 162-178. http://dx.doi.org/10.1075/lplp.7.2.04vai

Walsh, E. A. (2011). The Irish language in the New York City metropolitan area: Promotion, revitalization, investment, and identity. Dissertation Abstracts International, A: The Humanities and Social Sciences, 72(1), 0381.

Watkins-Goffman, L. (2001). Lives in two languages: An exploration of identity and culture. Ann Arbor: The University of Michigan Press. 
Zentella, A. C. (Ed.) (2005). Building on strengths: Language and literacy in Latino families and communities.

New York, NY: Teachers College Press.

\section{Appendix}

Survey questions on language use and language attitudes

Part B. Home Language(s)

6. What language(s) do you speak at home? (You may select more than one answer.)
(
) Spanish
) English
) Other language(s)

7. How often do you speak Spanish at home?
( ) Always
) Sometimes
) Rarely
) Never

8. How often do you speak English at home?
( ) Always
) Sometimes
) Rarely
) Never

9. How often do you speak languages other than Spanish and English at home?
(
) Always
) Sometimes
) Rarely
) Never

10. My father can/could speak: (You may select more than one answer.)
(
) Spanish
) English
) Other language(s)

11. My mother can/could speak: (You may select more than one answer.)
) Spanish
) English
) Other language(s)

12. In which language do/did your parents usually speak to each other at home?
(
) Spanish
) English
) Other language(s)

13. In which language does/did your father usually speak to you?
(
) Spanish
) English
) Other language(s)

14. In which language does/did your mother usually speak to you?
(
) Spanish
) English
) Other language(s)

15. In which language do you usually speak to your brother(s), sister(s), and/or cousin(s)?
( ) Spanish
) English
) Other language(s)

Part C. School Language(s)

16. How often do you speak Spanish at school?

( ) Always ( ) Sometimes ( ) Rarely ( ) Never

17. How often do you speak English at school?
(
) Always
) Sometimes
) Rarely
) Never

18. How often do you speak a language other than Spanish and English at school?
(
) Always
) Sometimes
) Rarely
) Never

19. Which language do you speak most often with your friends at school?
(
) Spanish
) English
) Other language(s)

20. Which language do you speak most often with other students at school?
(
) Spanish
) English
) Other language(s)

Part D. Language Use in the ESL Class

27. Which language do you speak most often in your ESL class?
( ) Spanish
( ) English
) Other language(s)

28. How often do you speak English in your ESL class?
(
) Always
) Sometimes
) Rarely
) Never
Under what circumstances do you tend to speak English in the ESL class? 
29. How often do you speak Spanish in your ESL class?
(
) Always
) Sometimes
) Rarely
) Never

Under what circumstances do you tend to speak Spanish in the ESL class?

30. How often do you speak a language other than Spanish and English in your ESL class?
( ) Always
( ) Sometimes (
) Rarely
) Never

Under what circumstances do you tend to speak that language in the ESL class?

33. Which language do you speak most often when you work in pairs / small groups in your ESL class?
( ) Spanish
) English
) Other language(s)
Can you explain why?

34. (If your answer for Question 33 is Spanish or other language(s), answer Question 34. If your answer for Question 33 is English, skip question 34.)

Do you feel peer pressure not speaking English when working in pairs / small groups in your ESL class?

$$
\text { ( ) Yes ( ) No }
$$

(If your answer is Yes, answer the following question.)

What kinds of peer pressure do you feel?

Part G. Language Attitudes

53. How well do you like English as a subject?

$\begin{array}{lll}(\quad) \text { Very much } & (\text { ) Somewhat } \\ (\quad) \text { Not very much } & (\text { ) } & \text { Not at all }\end{array}$

Can you explain why you like/don't like it?

54. How useful are ESL classes in general?

$\begin{array}{lll}(\quad) \text { Very useful } & (\quad) \text { Quite useful } \\ (\quad) \text { Not very useful } & (\quad) \text { Not useful at all }\end{array}$

What makes you think so?

55. How necessary is it that high school students in California should take ESL courses?
( ) Very necessary
) Quite necessary
( ) Not very necessary
) Not necessary at all

What makes you think so?

56. How necessary is it that students should speak only English in the ESL class?
( ) Very necessary
( ) Quite necessary
( ) Not very necessary
( ) Not necessary at all

Can you explain why you think so?

57. How necessary is it that students should be allowed to speak Spanish in the ESL class?
( ) Very necessary
( ) Not very necessary
( ) Quite necessary
( ) Not necessary at all

Can you explain why you think so?

58. How necessary is it that students should be allowed to speak a language other than Spanish and English in the ESL class?
( ) Very necessary
( ) Not very necessary
( ) Quite necessary
( ) Not necessary at all

Can you explain why you think so? 
59. Do you agree with the statement that in California being able to speak Spanish is more important than being able to speak English?
( ) Strongly agree
( ) Agree
( ) Strongly disagree
( ) Disagree

Can you explain why you think so?

60. Do you agree with the statement that in California being able to speak English is more important than being able to speak Spanish?
( ) Strongly agree
( ) Agree
( ) Disagree
( ) Strongly disagree

Can you explain why you think so?

61. Do you agree with the statement that in California being able to speak Spanish is as important as being able to speak English?
( ) Strongly agree
( ) Agree
( ) Disagree
( ) Strongly disagree

Can you explain why you think so?

62. How important is it that people in California should be able to speak Spanish?
( ) Very important
( ) Not very important
) Quite important
) Not important at all

Can you explain why you think so?

63. Do you agree with the statement that people in California who do not speak Spanish should be encouraged to learn it?
( ) Strongly agree
( ) Agree
( ) Disagree
( ) Strongly disagree

Can you explain why you think so?

64. How important is it that people in California should be able to speak English?
( ) Very important
( ) Quite important
( ) Not very important
( ) Not important at all

Can you explain why you think so?

65. Do you agree with the statement that people in California who do not speak English should be encouraged to learn it?
( ) Strongly agree
( ) Disagree
( ) Agree
( ) Strongly disagree

Can you explain why you think so?

66. Do you agree with the statement that it is sufficient for people in California to speak only Spanish?
( ) Strongly agree
) Strongly agree
) Disagree
) Agree
( ) Disagree
( ) Strongly disagree

Can you explain why you think so? 